Section Editor Mitchell S.V. Elkind, MD, MS

Matteo Impellizzeri, MD

Francesca Spagnolo, MD

Lidia Sarro, MD

Vittorio Martinelli, MD

Giancarlo Comi, MD

Maria A. Volonté, MD

Correspondence $\&$ reprint requests to Dr. Impellizzeri: m.impellizzeri@studenti.unisr.it

\title{
Teaching Video NeuroImages: Speech-induced oromandibular dystonia relieved by singing
}

무

We report a rare task-specific dystonia ${ }^{1,2}$ in a 26 -yearold man with a 4-year progressive speech disorder characterized by oromandibular spasms. Family and medical history were unremarkable; he was never exposed to neuroleptic drugs or toxic agents. Neurologic examination revealed only speech-induced oromandibular dystonic movements, characterized by forced jaw opening, interfering with speech (video on the Neurology ${ }^{\circledR}$ Web site at www.neurology.org). However, he was able to sing and to perform other voluntary activities (swallowing, drinking, chewing). Laboratory tests and brain magnetic resonance scans were normal. He received a placebo injection with no benefit. Trihexyphenidyl was started with moderate benefit. This rare form of dystonia is sometimes triggered by praying, ${ }^{1,2}$ resembling task-specific occupational dystonias.

\section{REFERENCES}

1. Ilic TV, Pötter M, Holler I, Deuschl G, Volkmann J. Prayinginduced oromandibular dystonia. Mov Disord 2005;20: 385-386.

2. Bonanni L, Thomas A, Scorrano V, Onofrj M. Task-specific lower lip dystonia due to mantra recitation. Mov Disord 2007; 22:439-440.
Supplemental data at www.neurology.org
From the Department of Neurology, INSPE, San Raffaele Scientific Institute, Milan, Italy.

The authors report no disclosures relevant to the manuscript. Go to Neurology.org for full disclosures. 


\title{
Neurology
}

\author{
Teaching Video NeuroImages: Speech-induced oromandibular dystonia relieved by \\ singing \\ Matteo Impellizzeri, Francesca Spagnolo, Lidia Sarro, et al. \\ Neurology 2012;79; 184 \\ DOI 10.1212/WNL.0b013e3182752c90
}

This information is current as of November 19, 2012

$\begin{array}{ll}\begin{array}{l}\text { Updated Information \& } \\ \text { Services }\end{array} & \begin{array}{l}\text { including high resolution figures, can be found at: } \\ \text { http://n.neurology.org/content/79/21/e184.full }\end{array} \\ \text { Supplementary Material } & \begin{array}{l}\text { Supplementary material can be found at: } \\ \text { http://n.neurology.org/content/suppl/2012/11/18/79.21.e184.DC1 }\end{array} \\ \text { This article cites } 2 \text { articles, } 0 \text { of which you can access for free at: } \\ \text { http://n.neurology.org/content/79/21/e184.full\#ref-list-1 }\end{array}$

Neurology ${ }^{\circledR}$ is the official journal of the American Academy of Neurology. Published continuously since 1951, it is now a weekly with 48 issues per year. Copyright (C 2012 American Academy of Neurology. All rights reserved. Print ISSN: 0028-3878. Online ISSN: 1526-632X.

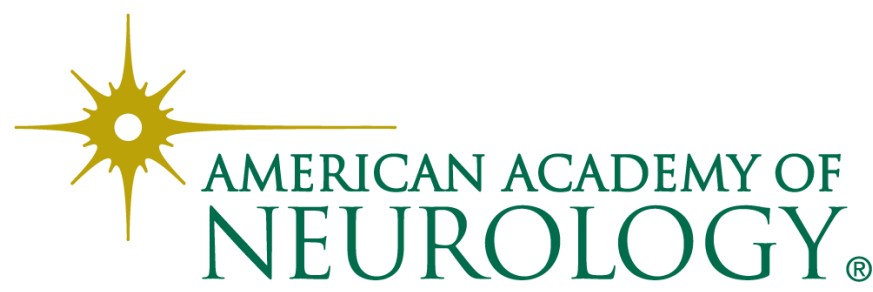

